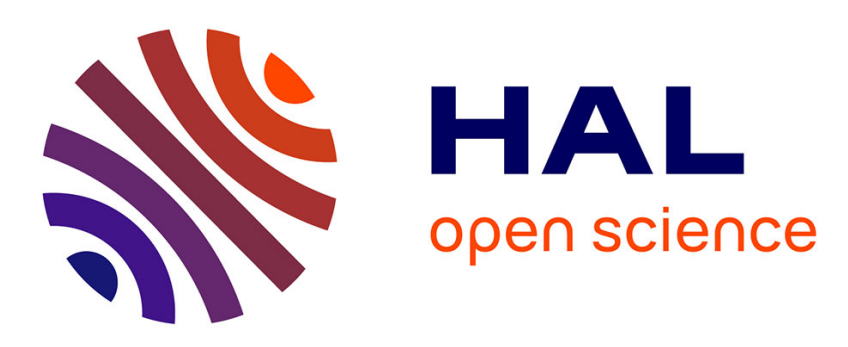

\title{
The gold, peoples and multiple frontiers of French Guiana
}

\author{
Michel Jébrak, Arnauld Heuret, Pierre Rostan
}

\section{To cite this version:}

Michel Jébrak, Arnauld Heuret, Pierre Rostan. The gold, peoples and multiple frontiers of French Guiana. The Extractive Industries and Society, 2021, 8 (1), pp.8-22. 10.1016/j.exis.2020.11.005 . hal-03393751

\section{HAL Id: hal-03393751 \\ https://hal.science/hal-03393751}

Submitted on 27 Oct 2021

HAL is a multi-disciplinary open access archive for the deposit and dissemination of scientific research documents, whether they are published or not. The documents may come from teaching and research institutions in France or abroad, or from public or private research centers.
L'archive ouverte pluridisciplinaire HAL, est destinée au dépôt et à la diffusion de documents scientifiques de niveau recherche, publiés ou non, émanant des établissements d'enseignement et de recherche français ou étrangers, des laboratoires publics ou privés. 


\title{
The gold, peoples and multiple frontiers of French Guiana
}

\author{
Michel Jébrak ${ }^{\mathrm{a}, *}$, Arnauld Heuret ${ }^{\mathrm{b}}$, Pierre Rostan ${ }^{\mathrm{c}}$ \\ ${ }^{\text {a } U n i v e r s i t e ́ ~ d u ~ Q u e ́ b e c ~ a ̀ ~ M o n t r e ́ a l, ~ D e ́ p a r t e m e n t ~ d e s ~ S c i e n c e s ~ d e ~ l a ~ T e r r e ~ e t ~ d e ~ l ' A t m o s p h e ̀ r e, ~ C P 8888 ~ C e n t r e-V i l l e, ~ M o n t r e ́ a l ~(P Q) ~ H 3 C 3 P 8, ~ C a n a d a ~}$ \\ ${ }^{\mathrm{b}}$ Université de Guyane / UMR 5243 Géosciences Montpellier, Campus de Troubiran, 2091 route de Baduel, 97300 Cayenne, France \\ ${ }^{\mathrm{c}}$ Bureau d'études MINE\&AVENIR, 97300 Cayenne and 05380 Châteauroux-Les-Alpes, France
}

\section{A R T I C L E I N F O}

\section{Keywords:}

Amazon

History

Extractive frontier

Gold industry

Small-scale mining

\begin{abstract}
A B S T R A C T
French Guiana is well endowed with gold like its neighbours in the Proterozoic Guiana Shield, yet it has no industrial mines, and most of the current production comes from illegal Brazilian miners. This situation is rooted in the history of its extractive frontiers, which began with the discovery of gold in 1855. French Guiana experienced two gold rushes influenced by the price of gold, first during the gold standard period, he second during the Chinese supercycle. The first wave of diverse ethnic groups searching for El Dorado came mainly from the Caribbean and Metropolitan France. Most companies did not survive the lack of infrastructure, the harsh rainforest conditions, and the end of the gold standard. After 1910, the frontier disintegrated due to the remoteness of the mine sites and the State's inability to control the territory. The current commodity frontier is a combination of an industrial front driven by French and international investments in the Northern Belt, and an artisanal illegal infiltration of Brazilian garimpeiros moving north of the Amazonian front. The shallowness of the commodity frontier results of unfavourable environmental conditions, the sparse population relative to land, the disconnect between the Paris-driven political system.
\end{abstract}

\section{Introduction}

Metal resources have been found on the margins of civilization for at least 3000 years. From the Bronze Age to the Iron Age, centres of development near the sea or in the heart of agricultural plains extracted metals from increasingly distant mountain sources (Barbier, 2012). Thus, the metals trade developed by the Phoenicians and the Han Dynasty marked the origin of long-range international trade. Amongst the metals traded and transported, gold, silver and copper, and to a lesser extent tin, emerged very early on as essential commodities in overland and maritime commerce.

As early as the 16th century, the quest for precious metals was active in North and South America. In the north, Turner (1893) conceptualized the idea of 'frontier' to describe the westward migration of American settlers. He laid out how different types of activities - mining, agriculture, and industry - unfold in time and space. Social scientists have more recently used the frontier concept to analyse capitalist expansion and global-local connections (Moore, 2010; Barbier, 2012; Luning and de Theije, 2019). Each frontier is the outcome of numerous factors, including geology, environment, technology, cultural practices, and systems of governance. The result is diverse 'mining constellations'
(Verbrugge and Geenen 2019), and thus different kinds of mining territories.

In northeastern South America, gold exploration and mining were driven by several groups of people in search of El Dorado, mainly coming from the Caribbean, Europe, Brazil and North America along different migratory paths. Each group had its own representation, knowledge and investment capacity. In French Guiana, the mining frontier has expanded twice since the mid-19th century, but the territory never moved toward sustainable development. On the other hand, the gold industry in present-day Suriname and Guyana (formerly British Guiana) plays a prominent role in employment and government revenues, compared to French Guiana, where only small-scale mines have been developed. Official gold production does not significantly contribute to the local economy, and illegal mining destroys the Amazon rainforest and contributes to international black-market.

French Guiana is therefore a singular mining territory compared to its neighbors. How then can the frontier concept be applied in the context of the Amazon rainforest of French Guiana? Following Moore (2010), two aspects of the commodity frontier in French Guiana require further examination. First, how did its frontier expand geographically, and can it be mapped? It remains unclear whether it is possible to define

\footnotetext{
* Corresponding author.

E-mail address: Jebrak.michel@uqam.ca (M. Jébrak).
} 
a single commodity frontier in French Guiana, as is often done so in other gold-rich territories (Barbier, 2012). Second, why has French Guiana's frontier not deepened (i.e. evolve toward industrialization, attract more diverse groups of people involvements, or develop strong linkages with areas with denser populations and access to international markets)? Is this perhaps due to the natural mineral endowment, the population, or one or more of the political specificities of French Guiana?

This paper will first discuss how the frontier concept has evolved since it was advanced by Turner (1893) before presenting the particularities of French Guiana as a mining territory. We then discuss the specificities of the gold frontier in French Guiana as a function of the gold mining history, highlighting the significant influence of the uniqueness of the early political scene in this French territory in South America. Additional data on historical economic activities, gold production, and migrations can be found in the comprehensive studies of Petot (1986, 1993), Mam Lam Fouck (2002) and Piantoni (2009).

\section{A brief review of the frontier concept}

Frontiers are a hot topic in discussions about the dwindling 'free space' around the world. Billington (1966) defined a frontier as "a geographic region adjacent to the unsettled portions of the continent in which a low man-land ratio and unusually abundant, unexploited, natural resources provide an exceptional opportunity for social and economic betterment to the small-propertied individual." According to Geiger (2009), it "is a spatial concept that tries to capture social dynamics." When Turner (1893) first established the concept, he defined it as the transformation of 'wild spaces' into civilized spaces, an unavoidable but desirable process, and one that follows a linear, teleological pathway. The notions of conquering and subjugating peripheral areas and of 'nationalizing space' form the core of the concept, along with the belief that these frontier regions are underused, underpopulated, and under-civilized. Walter Prescott Webb (1952) expanded the concept, starting with the new land discovered by Columbus and culminating with the closure of the frontiers at the end of the 19th century.

The link between frontier expansion and economic development has been widely adopted (Barbier, 2005). Four phases are recognized in the classic pattern of expansion: (1) initial exploration, discovery, and small-scale extraction of mineral resources; (2) development of large-scale extraction activities, usually for commercial export; (3) agricultural conversion of land and permanent settlements; and (4) industrial activities and urbanization (Barbier, 2012). The value of the concept is that it may serve as a heuristic device to identify spaces around the globe (Geiger 2009). It grounds and defines abstract processes in concrete actions, effects, spaces, and places. For instance, the Brazilian authorities started applying the concept to the Amazon region in 1974, designing it as a 'natural resources frontier' that was supposed to follow the 'Turner Utopia' (Schmink and Wood 1992; Da Silva Enriquez and Drummond, 2010; Le Tourneau, 2019).

However, the Turner-Webb frontier theory is outdated: it drew meaning only from the perspective of the colonizing culture and did not consider the local occupants (Geiger, 2009; Barbier, 2012). Given that the conquest of the Americas was destructive to both the environment and indigenous peoples, Verbrugge and Geenen (2019) state that frontiers arise from acts of colonialism rather than from the expansion of 'civilization' into 'unused' or 'barbarian' lands. Frontiers are contact zones where friction can emerge at any place where extraction commands access (Tsing, 2005). Moreover, in the 1980s, the Turner-Webb concept did not fit with the decline of Western economies. Clearly (1993) claims that "the frontier has collapsed" in South America.

The changes that have unfolded worldwide since the early-1990s, notably globalization, demanded a new academic interpretation of the frontier concept (Moore, 2000; Barney, 2009; Kröger, 2017). The emergence of a new commodity wave in response to the rise of the Asian economy provoked a structural shift in the mining industry and a sharp increase in the number and intensity of mining-related conflicts, especially along the borders of sparsely populated zones, such as the Sahel, Arctic and Amazonia (Jébrak, 2015; Sprague, 2015). The frontier concept needed political and ecological reframing as well as deconstruction. The upscaling of the size, speed and intensity of the resources industry squeezed the steps involved in Turner's frontier development. In contrast, the advent of new actors complicated the behaviour of the frontier. Commodity frontiers for metals are places with rich ores, however distant from centres of consumption (Moore, 2000). The very notion of frontier grew from a historical and geographical concept into the multifaceted processes underway in contemporary extraction areas, mobilizing economic, political and social sciences. Moore (2000) distinguished two aspects. On the one hand, the deepening of a commodity frontier involves the intensification of appropriation through increased inputs and various social and technological innovations, which could result in increased metal production. On the other hand, the 'widening' of such a frontier refers to a geographical expansion into new territories.

From the outside, commodity frontiers appear to be about territorial and symbolic forms that appropriate unpaid resources, delivered by humans and natural processes, to benefit commodity production. In a Marxist interpretation, such frontier movements appear essential because they allow capitalists to exploit, free of charge, natural resources and cheap labour for profit (Moore, 2014). Commodity frontiers engage a large number of people and networks (multinationals, NGOs). On the other hand, frontiers can be seen from within as relational zones of economy, nature and society, where new forms of social relations and systems of legality are rapidly established in response to market imperatives (Barney, 2009; Richardson and Weszkalnys, 2014). A frontier may not appear as "a place or a process but as an imaginary object capable of moudling places, people and processes" (Tsing, 2003). In this vision, a frontier is a hybrid object, beyond the nature-culture divide (De Jong et al., 2017). More recently, however, it has been suggested that such theories hide the existence of real physical and landscape-altering frontiers that have been dynamized by recent commodity expansions (Kröger, 2017).

The frontier concept has been used differently on different continents. In North and South America, it refers to designing the borders of sparsely populated areas, whereas in Africa it applies to the percolation of artisanal mining into existing political entities (Kopytoff, 1987; Grätz, 2004). Therefore, extraction frontiers can be the result of different types of mining activities, ranging from artisanal to industrial mining. This heterogeneity could occur within the same territory as exemplified by the Philippines (Verbrugge and Geenen, 2019), where a variety of mining constellations have been identified. They suggest that frontiers can be understood as either "zones of incorporation", "zones of destruction" or "zones of friction".

Such theorization of the frontier process does not appear neutral from the point of view of both concepts and semantics. It emphasizes the negative aspects of frontier development, with an inverse excess of Turner's positive aspects. Also, it tends to reduce the evolution of mining territories to the world dynamics of global capitalism, reducing the role of local factors to simple variations on the theme. But not all territories are equal. It is not only the weight of capitalist pressure that intervenes as extractive frontiers occurred long before the advent of capitalism (Barbier, 2012). Thus, in South America, the mythology of El Dorado has been an essential component in the imaginations of migrants from neighbouring countries, such as Brazil, and the West Indies (Perez, 1973). As Kröger (2017) stated, frontiers are real, physical/landscape-altering; they should be studied as 'frontiers of existence', based on geographical and historical observations.

Therefore, we decided to treat the commodity frontier concept as a descriptive geographical concept illustrated by increasing population densities and greater deforestation levels in areas outside state regulations (Barbier, 2005; Kröger, 2017). Acknowledging that 


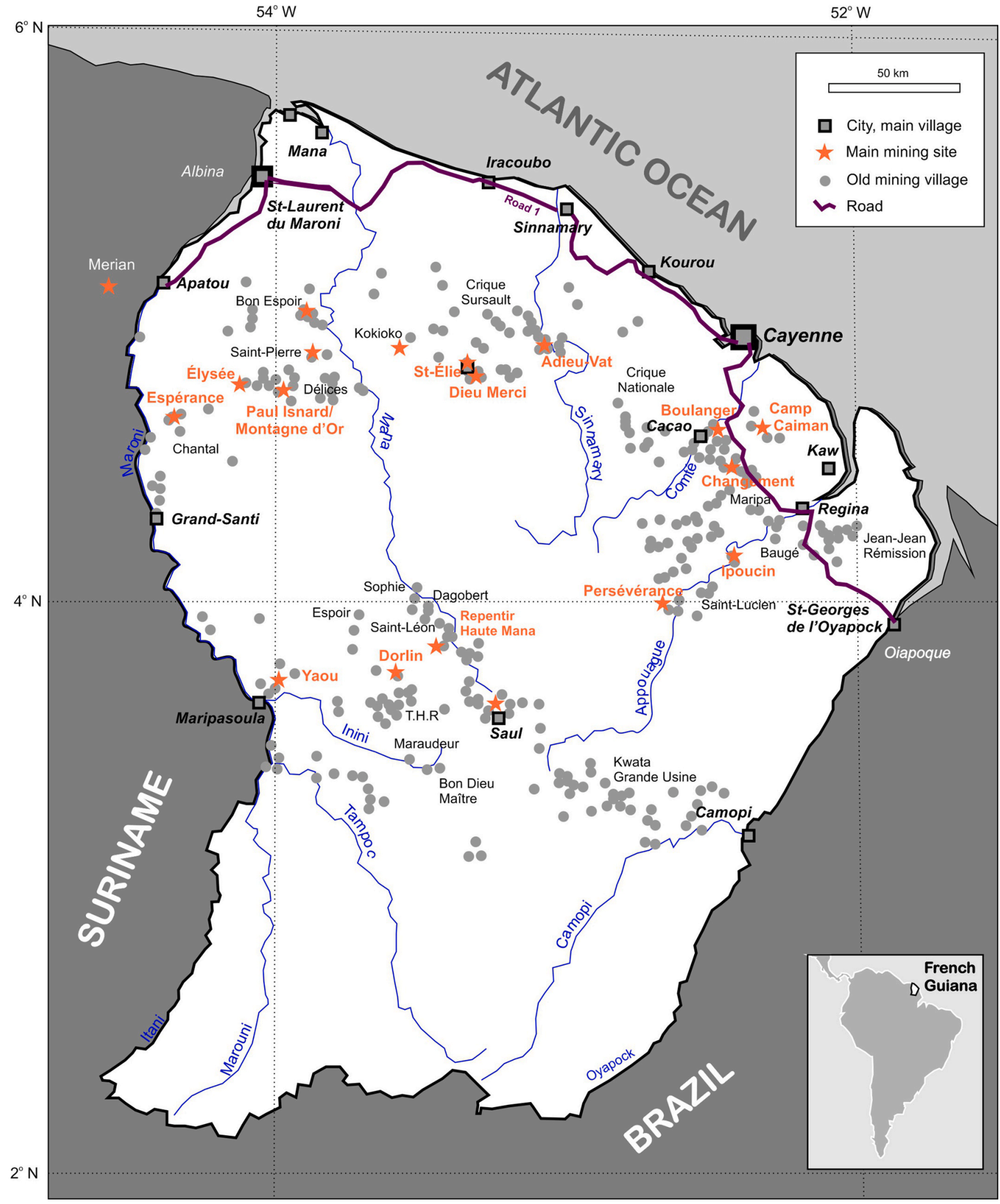

Fig. 1. Location map of French Guiana in South America showing the main gold occurrences and sites cited in the text. The distribution of mining villages is from Abonnenc and Jolivet (1979). 
representations of geographical space always emanate from a particular standpoint, we will try to be as inclusive as possible when discussing the diverse populations involved.

\section{Specificities of French Guiana}

French Guiana shares numerous characteristics with its two Guianese neighbours, Suriname and Guyana. However, as the last European overseas department in South America, it has a particular political and economic history that has shaped the dynamics of its extractive border. These features are briefly examined in this section of the paper.

\subsection{Geology and environment}

Most of French Guiana is underlain by rocks formed during the Proterozoic Transamazonian orogen. These rocks are part of the Guiana Shield, a vast geological entity that extends from Venezuela to Amapá (northeast Brazil).

Since the pioneering work of Von Humboldt in southern Venezuela around 1800, the geology of the Guiana Shield remains poorly understood compared to its North American or African equivalents. Gold is abundant across the Guiana Shield, from Brazil to Venezuela. In French Guiana, gold is hosted in two specific Transamazonian rock belts: the Northern Greenstone Belt, along the Atlantic coast, and the Southern Greenstone Belt, in the deep interior between Maripasoula and Camopi (Fig. 1) (Kroonenberg et al., 2019). Two categories of gold deposits are distinguished, each of which demands specific extraction and metallurgical techniques and different levels of know-how and investment:

- Primary deposits formed during the Proterozoic eon. Three types are recognized: (1) Early massive sulphide deposits, such as Montagne d'Or/Paul Isnard, representing the accumulation of iron, copper and other sulphides in volcanic rocks on the Proterozoic seafloor (Guiraud et al., 2020); (2) Disseminated gold deposits, such as Espérance or the large industrial deposits of Merian and Rosebel (Suriname), composed of disseminated sulphides most typically in sedimentary or plutonic rocks; and (3) Quartz vein gold (orogenic) deposits, often low-tonnage but high-grade (Milési et al., 1995). Both disseminated gold and quartz vein deposits resulted from the infilling of faults by hydrothermal fluids at the end of mountain belt formation. They can be deeply rooted, to vertical depths of $3 \mathrm{~km}$, amenable to artisanal and small-scale mining near the surface and industrial-scale mining at depth. Massive sulphide and disseminated gold deposits usually form bulk tonnage low-grade deposits that require major investment and industrial capacities if mining is to be viable. Gold can be coarse or invisible, and the mineralogical position of gold allows for recovery by simple means, such as gravimetric methods, or by chemical treatment, including artisanal mercury or industrial cyanide extraction (Thomassin et al., 2017; Scammacca et al., 2020).

- Secondary deposits form through the alteration of primary deposits (in situ lateritic, eluvial, colluvial or alluvial accumulations) characterized by small individual gold grains in loosely packed or unconsolidated sediments. Secondary deposits can be mined as small-scale operations or using modern mining equipment (Cremers et al., 2013; Mattheus, 2018).

The humid equatorial Amazon rainforest covers 96\% of French Guiana, making the territory difficult to penetrate. Biodiversity is incredibly rich, and a national park (Guyana Amazonian Park) protects half of the land. To the north, a wide coastal strip made up of savannas, ranging from 15 to $50 \mathrm{~km}$ each, extends $350 \mathrm{~km}$ along the Atlantic coast, limiting the expansion of ranching and farming activities. There are no hinterland roads, and 7 of the 22 municipalities in French Guiana have no road access.

\subsection{Peoples}

The population of French Guiana in 2020 is almost 300,000. The density is only 3.3 habitants per square kilometre, with ten times the population along the coast versus the nearly empty hinterland. Like Suriname and British Guyana, French Guiana is characterized by a remarkably diverse population from several migratory origins. Human history has mixed many socio-cultural groups together: Amerindians from different indigenous nations, Metropolitan whites, Creoles, Maroons (locally called Bushinenge), Chinese, and the more recent migrants from Laos, Haiti, Suriname, and Brazil.

The 11,000 Amerindians of French Guiana are legally French citizens. There is no customary land ownership (Davy et al., 2016). The symbolic and political weight of indigenous populations has strengthened since the 1980s (Collomb, 2006). The Guianese Creole people share a common Creole language, culture, and French citizenship. They are the product of an assimilation process that dates back to the late 19th century (Strobel, 1998; Piantoni, 2009). They also share a common history inherited from the slave trade and its abolition. By the time slavery was abolished in 1848, people of African origin had formed the nucleus of the French Guianese Creole identity (Jolivet, 1982), which evolved with the assimilation of successive waves of migrants (Caribbean, Asian, Middle Eastern, etc.).

The history of slavery in Suriname also influenced French Guiana history. In 1765, the Dutch colony had more than 50,000 slaves working in 591 plantations (Dupuy, 2002). At the end of the 18th century, some runaway slaves, called Maroons or Bushinenge, escaped the Surinamese plantations and established independent communities in the rainforest (namely the Alukus, Djukas and Saramacas). Most were descendants of the Ashanti and Fanti peoples of the Gold Coast (present-day Ghana), and their culture incorporated elements from diverse African cultures as well as adaptations to their South American environment and contacts with Amerindians (Jolivet, 1982; Josiah, 2011; Fortes-Lima et al., 2017). Djuka and Aluku settled along both French and Dutch sides of the Maroni River (Piantoni, 2006).

In contrast to its neighbours, French Guiana remains strongly dependant on its European roots, combining a favourable economic status, thanks to French and European transfers, with dual Paris and Cayenne political administration. French Guiana is a part of the European Union in South America. Regional integration remains challenging due to neighbouring countries producing the same goods at a lower cost and diverging development strategies.

\section{A historical narrative of gold in French Guiana}

The gold mining history in French Guiana is relatively short, only starting around 150 years ago.

The borders of French Guiana have been defined along two major rivers (Maroni, Oyapock) that constitute significant circulation corridors within the rainforest. The peoples of the same name that live on the banks of these rivers formed communities that cannot be divided by political borders or controlled by either government (Hyles, 2014). As a result, French Guiana has semi-permeable borders with neighbouring countries that allowed numerous migrations from Suriname and Brazil.

Four periods are recognized in the history of gold mining in French Guiana: (1) the first gold rush (1858-1880) followed by (2) a peak production period (1880-1914), (3) a decline of activities spanning the world wars (1915-1945) and continuing after (1950-1970), and (4) a second gold rush, both artisanal and industrial, beginning in 1980. The four periods are best illustrated by the pattern of reported official gold production (Fig. 2) and the geographic distribution of mines (Fig. 3). However, the data provide only a partial view of a given period as they represent official mining statistics only. Illegal mining is almost impossible to map over time because gold production can only be estimated. Furthermore, the surface area covered by mining licences provides a biased (maximum) estimate of the land used by official mines since the 


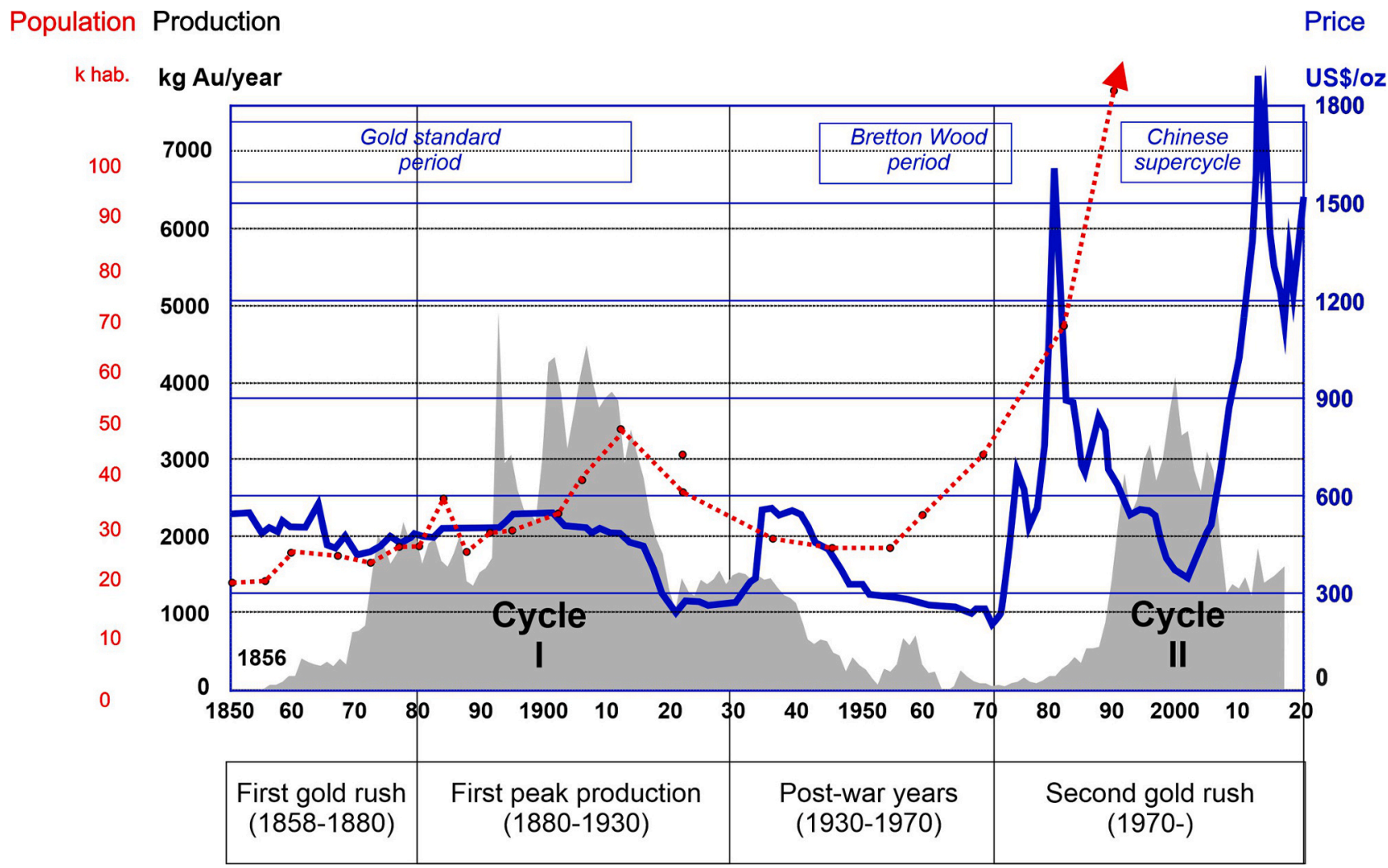

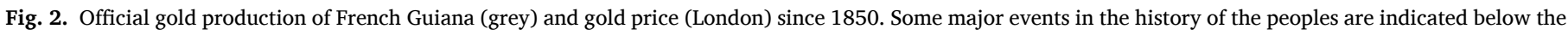
chart; see text for details.

granting of mining licenses does not systematically lead to exploitation.

\subsection{First gold rush (1858-1880)}

Gold and precious stones have been extracted in Amazonia since colonial times in a series of periodic booms. One of the oldest rushes in Brazil started in 1690 around Ouro Preto. Many deposits were developed following the northward migration of Brazilian people (Le Tourneau, 2019), and garimpeiros became known as the most skilled gold miners in the Precambrian terranes of South America.

Slavery ended in 1848, before the first discovery of gold. For this reason, slaves were not used for mining in French Guiana, contrary to the situation elsewhere in South America, like Bolivia and Brazil (Daget, 1992; Daly, 2018). On the Guiana Shield, gold was discovered only in the mid-19th century, first in French Guiana (1854), then in British Guiana (1857) and Suriname (1879). Gold was formally discovered in French Guiana on the Approuague River by Paoline, a Brazilian metis from Ouro Prêto, and Félix Coüy, a French administrator. A gold rush began, with similarities to the gold rushes of California in 1848 and Australia in 1851 (Fig. 2).

The territory was subsequently explored from east to west, along the Northern Greenstone Belt. Major placers were discovered between 1859 and 1880, first along the Orapu and Comté rivers, then the Kourou River (1862), the Sinnamary River (Dieu-Merci in 1869, Adieu-Vat in 1866, and Saint-Élie in 1873), the Middle Mana River around Crique Lézard (Enfin, Elysée and Paul Isnard between 1873 and 1875), and finally the Upper Maroni River (Espérance region, around 1874). Following the first gold discovery, concessions quickly covered most of the Northern Greenstone Belt, the most accessible belt from the coastal areas (Fig. 3a).

As in all gold rushes, the first gold miners in French Guiana arrived from multiple directions. They were mainly single men travelling from the coastal fringe toward the sources of the rivers. Six years after the end of slavery, free workers were plentiful, and Guianese workers gradually shifted from agriculture to mining activities on placers (Piantoni, 2009). They were soon joined by contingents of French Metropolitans, Caribbean Creoles, and immigrants of all origins who arrived steadily and constructed a new Guianese Creole identity (Mam Lam Fouck, 1999; Piantoni, 2009). The contingent from the Caribbean region played a particularly important role in the Guianese gold rush. The Caribbean, long the scene of migration flows, saw new patterns emerge after the liberation of slaves, with movement either between islands or from small islands to South and Central America, often crossing language barriers (Domenach and Picouet, 1992). The immigrants to French Guiana came from the Lesser Antilles, driven by growing poverty and hardships on the sugar islands, mainly Saint Lucia but also Dominica, Guadeloupe and Martinique. There was no tradition of mining on these islands, and migrants moved directly from agriculture into a mining industry that was still at an early stage of development. They were seen only as labourers, and few opportunities arose for them to acquire knowledge and climb the mining and social hierarchies.

The desertion of the plantation system ruined the fragile economy of French Guiana. The European plantation owners virtually disappeared, some of them switching to gold mining (Mam Lam Fouck, 2002). Between 1855 and 1880, the State indeed granted mining concessions to the plantation owners to compensate for the financial losses engendered by the abolition of slavery. The imperial decree of 1858 assigned mining rights to the holder of a mining concession title and exploitation rights to the holder of an exploration title (Piantoni, 2009). Such binding legislation was unfavourable to artisanal mining (Petot, 1986). The substantial investments required to conduct exploration work prompted plantation owners, dignitaries and traders to create new companies to pool their financial and human resources.

Formal companies were not efficient, and their failures did not encourage local investment after 1870 . They used basic mining methods 

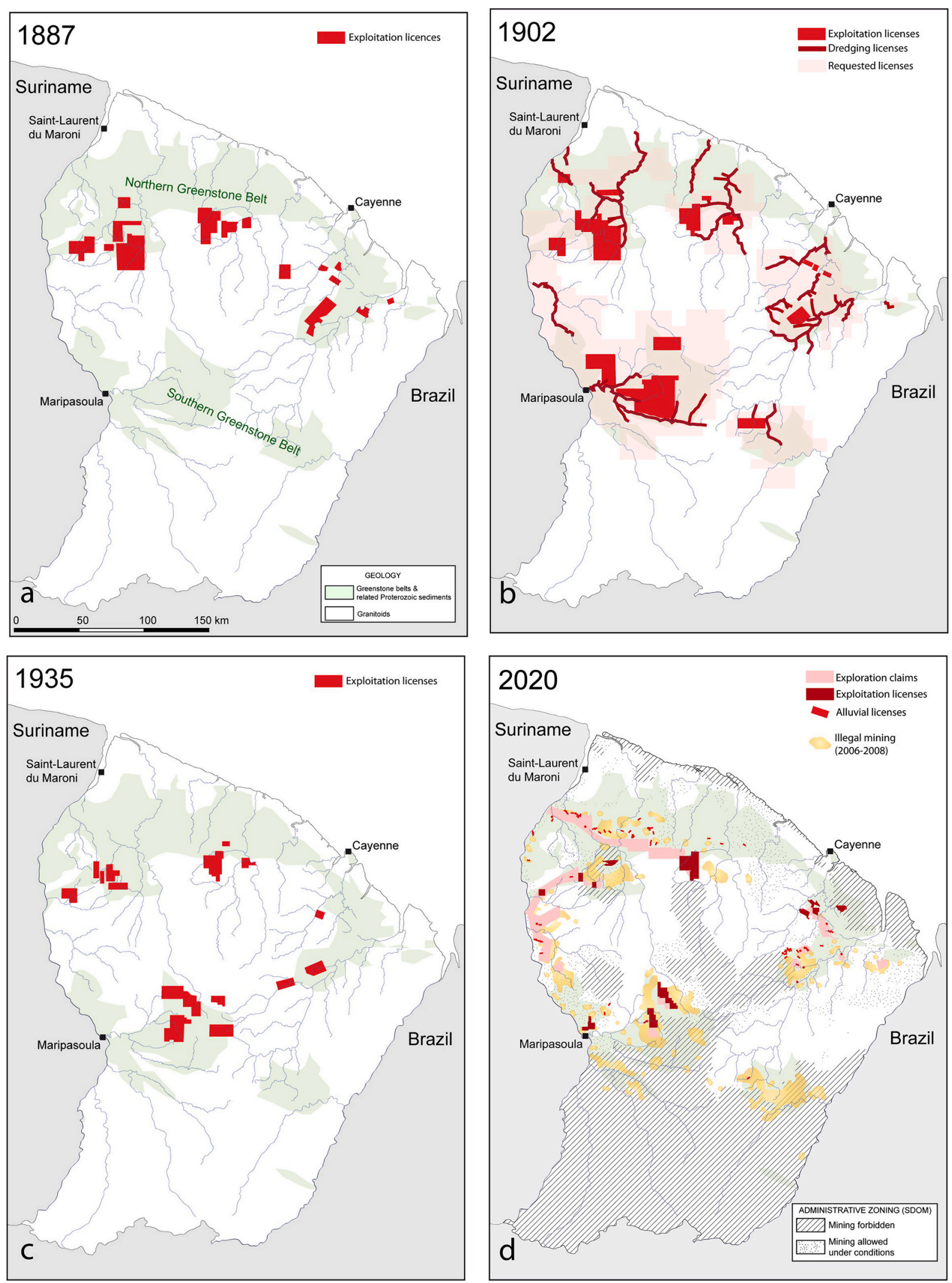

Fig. 3. Evolution of mining activities in French Guiana. (a) in 1887; (b) in 1902; (c) in 1935; (d) in 2020. Historical mining activity distribution data are from Coudreau (1887), Levat (1902), Bureau (1935). Present-day mining activity distribution has been retrieved from public datasets on 30/04/2020: http://www.guyane .developpement-durable.gouv.fr/, http://camino.beta.gouv.fr and http://www.mineralinfo.fr/. The present-day map shows both issued and requested licenses. The illegal mining data, from WWF (cited and published in Biancodini 2019), represent the cumulative areas of deforestation attributed to illegal mining from 2006 to 2008. Greenstone belt positions are from Vanderhaeghe et al. (1998). 
(Fig. 5a): first pans, mainly for prospecting, then the 'submarine' method, a primitive technique in which water carrying gold particles flows into a small canal built like a staircase, concentrating the gold in the outflow. Long Tom sluices were brought in from California in 1856 (Orru, 1999b) and could be run with a smaller workforce (Petot, 1986). However, after only one generation, the most accessible parts of the gold deposits had been mined out, and companies turned their attention to the untouched parts of placer deposits and weathered primary targets.

The Bushinenge contributed to mining development in French Guiana. Their navigation skills were exploited by gold panners and extraction companies to transport people, supplies and equipment up the rivers to the interior villages and placers (Mam Lam Fouck, 1999; Orru, 1999a). This economic activity was carried out by groups of men belonging to the same communities and supervised by a captain with delegated magico-religious authority. This function was largely assigned to the Boni on the placers of the Upper Maroni and Inini rivers, the Djuka on the Surinamese shore of Maroni, and the Saramaca on other rivers of French Guiana (Mana, Approuague, Sinnamary, Oyapock) (Heemskerk, 2000; Piantoni 2006; Jolivet, 2019). In 1860, an agreement was reached between France and the Ndyuka to facilitate the transfers along the Maroni River and allow more Bushinenge to set up in French Guiana. France officially recognized the Boni in 1887 (Urban, 2016).

Although not directly involved in mining due to a religious ban, the Boni quickly became an essential part of the gold production chain and received substantial benefits from trade and taxes on the extracted gold (Rodney, 1981; Hoogbergen et Kruijt, 2004; Fleury, 2018).

\subsection{First peak production (1880-1930)}

Gold completely dominated the economy of French Guiana from the 1880 s to WWI (Piantoni, 2009). The peak of annual gold production was 4.5 tonnes of gold in 1908 (Fig. 2), compared to the 1.2 tonnes produced in Suriname at that time (Heemskerk, 2000). Two different evolutions characterized the period from 1880 to 1930: (1) the attempt to mechanize operations as industrial companies developed mines on primary gold deposits or dredged large upstream placers, and (2) the later arrival of a new wave of Caribbean people during spontaneous gold rushes related to new placer discoveries, which continued until the early 20th century (Fig. 2). The competition between industrial companies and the spontaneous immigration of miners contributed to the dismantling of the gold industry in French Guiana.

Primary deposits became promising targets after the development of the El Callao district in Venezuela. Initially discovered by the Spanish at the beginning of the 19th century, the district was rediscovered by a Brazilian and a Frenchman in 1849 (Waszkis, 1993). Annual production rocketed from 0.1 tonne in 1871 to 5 tonnes in 1892 . The district became one of the richest in the world. After being widely publicized in Europe, the mining potential of the Guianas attracted numerous French capitalists, some of them already working in other parts of the French Empire. Publicly funded companies were able to finance the large investments needed to sink shafts and galleries and to commission processing plants to grind ore (Fig. $5 \mathrm{c}$ and d). French engineers used methods similar to those used back in France. The first attempts to mechanize primary deposits were by Compagnie Générale de la Mana at Elysée and by Société des Gisements d'Or at Saint-Élie in 1883, followed by Lalanne at Espérance and Adieu-Vat (1887), and later by Compagnie des Mines d'Or de la Guyane Française at Ipoucin (1890). At Saint Élie, several professional miners came from Europe (France, Italy) to work on underground operations. Gold production was successful only in the lode deposits of Adieu-Vat (Choubert, 1952) and part of Elysée. Most of the failures were due to the style of mineralization (disseminated and irregular), the difficulty in transposing mining techniques, and poor management.

This period marked the arrival of French engineers, such as Edouard Rey, Albert Bordeaux, Louis-Fernand Viala, Louis Pottereau, Henri Babinsky, Léon Delvaux and Léopold Collier de la Marlière (Dangloise and Pottereau, 1905), and then Pierre Delaître in 1933. The most remarkable was Edouard-David Levat, a mining engineer from École Polytechnique in Paris whose work improved the understanding of gold deposits and helped modernize mining processes (drilling, dredging, high-pressure jets). He published two landmark texts on gold in French Guiana and laid out a plan to build a mining railway connecting the main gold districts.

As alluvial deposits began to be depleted in the early 1890s, the advent of dredging spurred the exploitation of untouched alluvial and fluvial deposits below streams and swampy areas (Fig. 5b). The first gold dredges from California and New Zealand were a real technological leap in the mining industry, a by-product of advances in port and canal technologies. Built in Europe, usually in Holland or Scotland, the dredges were dismantled for transport by canoe through the rainforest to be rebuilt onsite at the deposit. With some weighing as much as 350 tonnes, they were enormous and costly machines for mining companies to buy and operate. The first dredges in French Guiana were built in 1899 by such European companies as the Compagnie des Dragages Aurifères de la Guyane Française on a tributary of the Sinnamary River (Crique Sursault). About 20 dredges were brought into the basins of the Sinnamary, Mana, Comté, Approuague and Maroni rivers (Rostan, 2010, Rostan, 2013). French mining companies also used crushers and railways in Saint Élie (operational in 1898) and high-pressure hydraulic mining to destructure the clayey material starting in 1896 (Orru, 1999a).

Even if French Guiana lay outside the main targets of Anglo-Saxon mining companies, they made some attempts in the early 20th century. Alexandre William Heydecker, a wealthy American, bought the Elysée placer in 1904 and worked with Jean Galmot, a French adventurer who became a Guianese deputy. Another American, P. Tiffany, installed two dredges on the Maroni in the 1920s.

This productive period ended in the early 20th century as gold deposits were depleted. The last dredge was installed on the Sinnamary in 1928. Inadequate prospecting, inappropriate equipment, and poor management soon meant the end for most mechanized operations.

Placer discoveries continued until the beginning of the 20th century, moving ever deeper into the hinterland along the Southern Greenstone Belt (Saïl region, Upper Mana and Maroni, Inini) and into the contested territories of Brazil to the east and Suriname to the west (Fig. 4). This period is best illustrated by the widespread distribution of requested and issued mining licences (Fig. 3b), which covered not only a large percentage of the Northern and Southern Greenstone Belts but also a priori barren grounds around the greenstone belts and along most of the main rivers (dredging licences). Even though this coverage may not be representative of the total exploited area (most of the requested and dredging licences are probably related to speculation issues rather than recognized deposits), it is undoubtedly indicative of the mining dynamics in the early 1900 s.

\subsection{The marauders period}

In French Guiana, spontaneous immigration contributed to the progressive dismantling of the gold industry. Unable to obtain concession titles, illegal miners from the Caribbean formed commandos of 'marauders' who attacked isolated placers. They created local gold rushes, mobilizing thousands of people, such as in Kokioko (Galmot, 1907; Petot, 1986). The civil authorities tried to regulate the activities by enforcing French regulations in the rainforest. Still, they were thoroughly unprepared, and after 1904, they were tolerated by the administration (Saussus and Mandrick, 2004). No longer able to ensure the protection of their worksites and without the support of the State, concession owners placed their land under 'tinkering', which allowed the marauders to extract the gold and set up business houses where they recovered the gold in exchange for materials and supplies, generally for around $10 \%$ of the production. This system allowed the owner to solve both the labour problem and the threat posed by marauders. The 


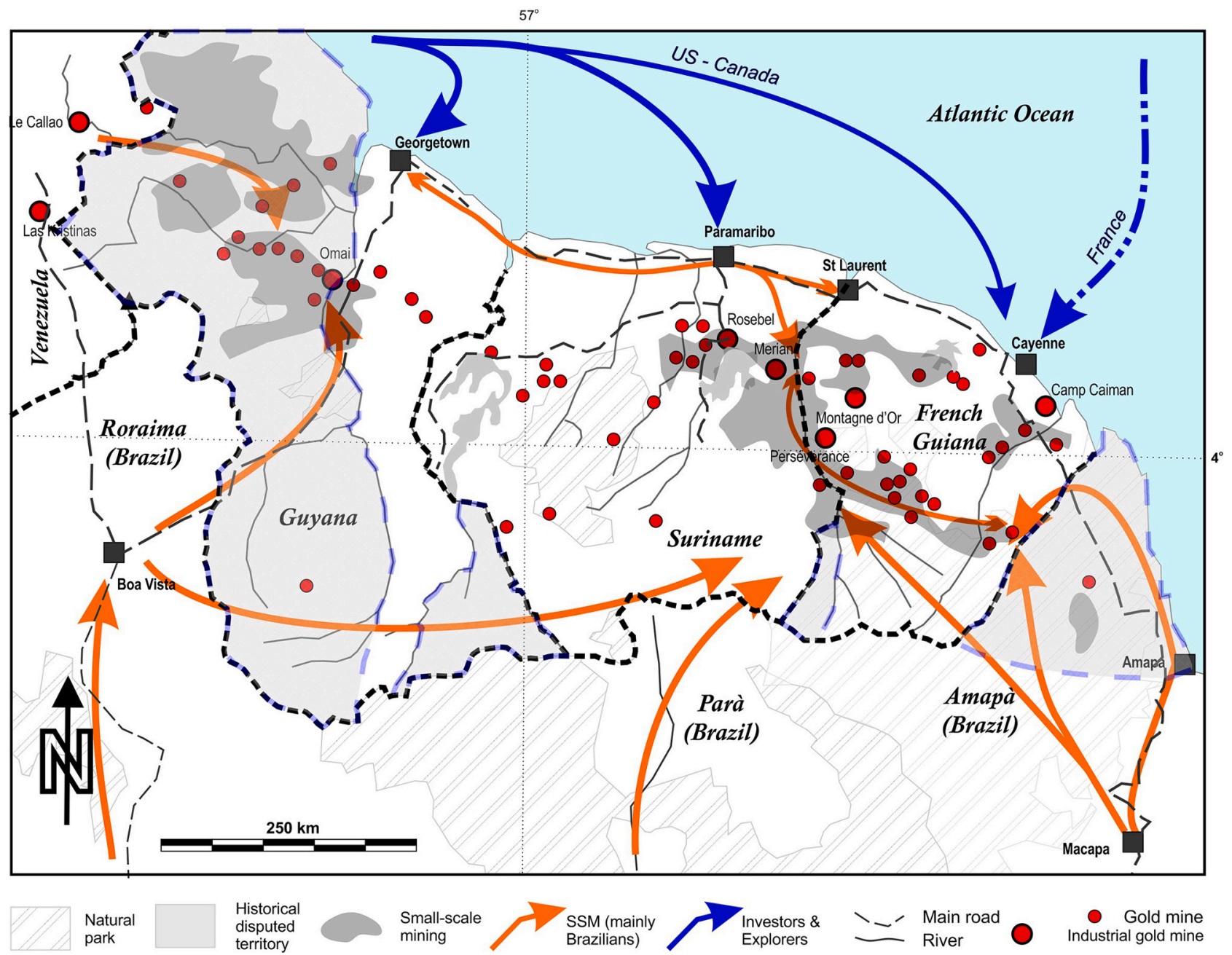

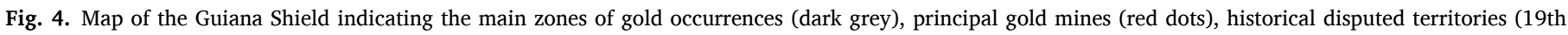

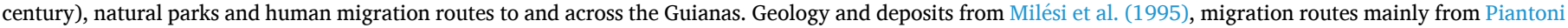
(2009) and Granger (2017).

concessionary companies were transformed into suppliers for upstream placer operations, selling food and manufactured products to the miners. Industrialization gradually ceased, and the cumulative area covered by official mining licences slowly decreased (Fig. 3c).

This period of intermixing populations contributed to the emergence of a Creole culture in the French Guiana hinterland (Strobel, 1998). Numerous villages (more than 300 now documented; Fig. 1) were built by a population of mining workers estimated to have reached 10, 000-12,000 in the 1920s (Orru, 1999a).

Mining techniques remained primitive for a long time. Artisanal operations relied on timber and water resources, emphasizing sluicing in small alluvial creeks and eluvial deposits (Fig. 3). The latter required a certain level of water management to ensure adequate water for processing, sometimes using a small canal dug directly in the ground. In the Saul area of central French Guiana, the periodic fluctuations in water abundance and scarcity turned artisanal mining into seasonal work (Rostan, 2014). When quartz-rich ore was available, miners used the primitive fire method to obtain small gold-rich blocks that could be hammered (Rostan, 2007).

Resource depletion and supply shortages during the world wars caused an inevitable decline in gold mining (Fig. 2). It was eventually relegated to the rank of 'subsistence activity' (Taubira-Delannon, 2000). Most marauders disappeared between 1920 and 1925, and rainforest villages were progressively abandoned during an exodus back to the coastal fringe during the mid-20th century. The number of small-scale miners decreased drastically to only 461 in 1961 (Orru, 1999a). The village of Saul, built by the Saint Lucian people, is one of the last-standing remnants of the Creole villages in the French Guiana hinterland.

\subsection{Post-war years (1930-1970)}

Artisanal mining operations continued after WWI even though the low price of gold, fixed by the Bretton Woods Agreement of 1944, did not warrant any significant investments for a generation. Technology slowly changed, with improvements to motors and pumps in the 1950s. (Fig. 6b). Several French Metropolitan entrepreneurs from the Massif Central in France, where gold had been mined since Roman times, or from the French colonial territories in Africa and Southeast Asia (Indochina), built new companies with some support from the local authorities (Petot, 1993). However, the lack of capital and expertise were major weaknesses. For instance, people from the Limousin region of France developed the first project in 1947 on Montagne de Kaw (Filon Trésor), but their inexperience led to failure just three years later. After quarries in Saint-Élie were developed for hydraulic mining, the first open pit mine became operational in 1960 on the Sophie veins, in the Upper Mana valley.

Several American entrepreneurs, investors and mining companies arrived in French Guiana after WWII. They started using draglines during the 1950s, most often caterpillar type (Fig. 6a), equipped with a 

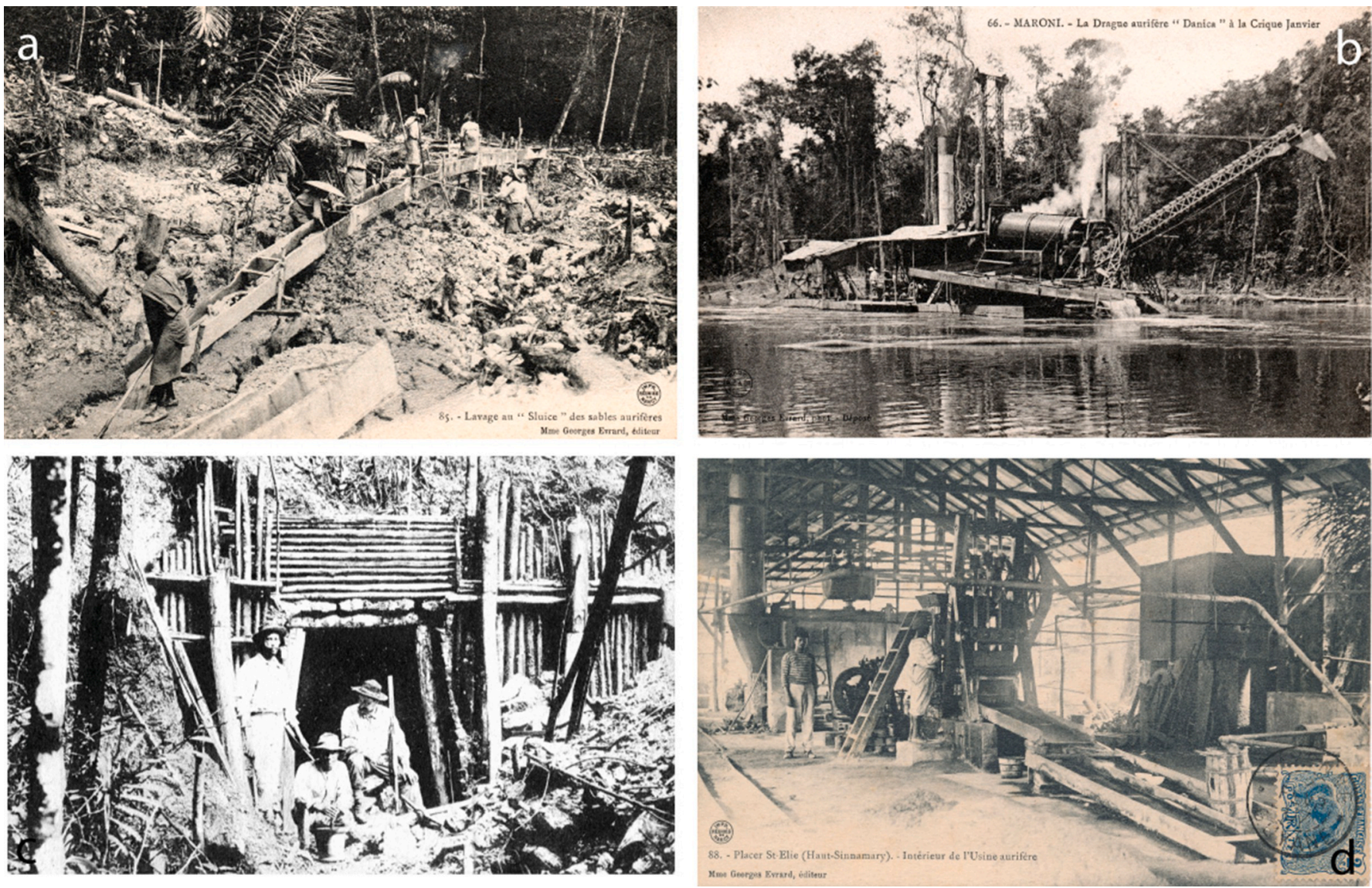

Fig. 5. Gold mining techniques used in French Guiana before WWII. a) Creole marauders working a sluice on an alluvial placer. Sluices are amongst the earliest artisanal methods used in French Guiana (postcard circa 1904; A. Heuret Collection); b) The Danica dredge, operated on the Sparwine River (Maroni region) since 1903, one of about twenty dredgers used along French Guiana rivers from the end of the 19th century. Dredges also marked the beginning of mechanized mining, which allowed gold to be extracted from untouched alluvial deposits in streams and swampy areas (postcard edited around 1904; A. Heuret Collection); c) Mine gallery entrance with wooden support structures. From the 1880s, this type of method was typically used for underground mining of quartz-bearing veins (picture taken in the late 19th century and edited for a 1930s postcard; A. Heuret Collection); d) Gold plant installed in 1898 at Adieu-Vat near Saint-Élie. The three-pestle Fraser \& Chalmers crusher made it possible to extract gold from primary quartz ore. This plant marks the beginning of mechanized gold mining in French Guiana (postcard circa 1904; A. Heuret Collection).

crane and buckets to recover underwater alluvium and feed a floating plant (Rostan, 2010, 2013, 2014). At the Boulanger placer, American technicians operated the equipment (Seyer, 1961). The English-speaking workers were mainly from Saint Lucia. The equipment remained active until 1979, when the operation returned to artisanal techniques. The Saint-Élie mine was also leased to Canadian American interests in 1948. Other examples of American interests include SERMAC's mine at Délices (1955) and Compagnie Minière de Paul Isnard (1966). Most of these enterprises failed, and the companies left French Guiana for Suriname during the 1960s and 1970s.

In the Keynesian era, the State began exploring for primary gold deposits (Lenormand and Lenormand, 1952), involving national (and regional) geological survey institutions: ORSTOM and BMG in the 1950s, and BRGM at the end of the 1960s. The geological mapping and mining inventory of French Guiana from 1975 to 1995 improved geological knowledge (Taubira-Delannon, 2000).

In the 1970s, business activity for mid-sized industrial companies was renewed after the gold-dollar exchange rate was abandoned, leading to a sharp hike in the price of gold and rising inflation. Mining resumed on abandoned placers. The emergence of open-air works with earthmoving equipment (mechanical shovels and trucks) breathed new life into the production. In 1978, the first suction dredgers appeared on Guianese rivers to exploit alluvial deposits on the river bottoms (Fig. 6b), a technique tested in Africa and the Brittany region of France in the 1960s. Mechanical shovels took over the dragline excavators throughout French Guiana to exploit gold-bearing sediments (Fig. 6d).

\subsection{Second gold rush (1990-present)}

By the end of the 1980s, a new gold rush was underway (Fig. 2). It was characterized by the immigration of Brazilians, who still comprise the main workforce since then, bringing with them new mining methods. They have been involved in both legal and illegal mining.

This situation should be reframed within the broader context of the northern Brazilian commodity frontier (Da Silva Enriquez and Drummond, 2010). Several penetration routes have allowed Brazilians to lay claim to more than half the Amazon Basin (Théry, 2003). During the mid-20th century, the mechanization of agriculture in Brazil pushed millions of farm labourers toward city favelas (slums) or to the north. By 2002, the population of Northern Amazonia had risen from 4 million to 20 million (Le Tourneau, 2009). Many small roadside farming operations failed, and the impoverished farmers moved into mining to become garimpeiros. A series of economic crises that struck Brazil in the 1970s and $80 \mathrm{~s}$ exacerbated the situation. During this period, extensive highway construction facilitated migrations into the Amazon region (Caviglia-Harris et al., 2013; Cremers et al., 2013; Le Tourneau, 2019). Several gold rushes took place after 1980 on Yanomami territory in the Brazilian state of Roraima (Godfrey, 1992; Sponsel, 1995). French 

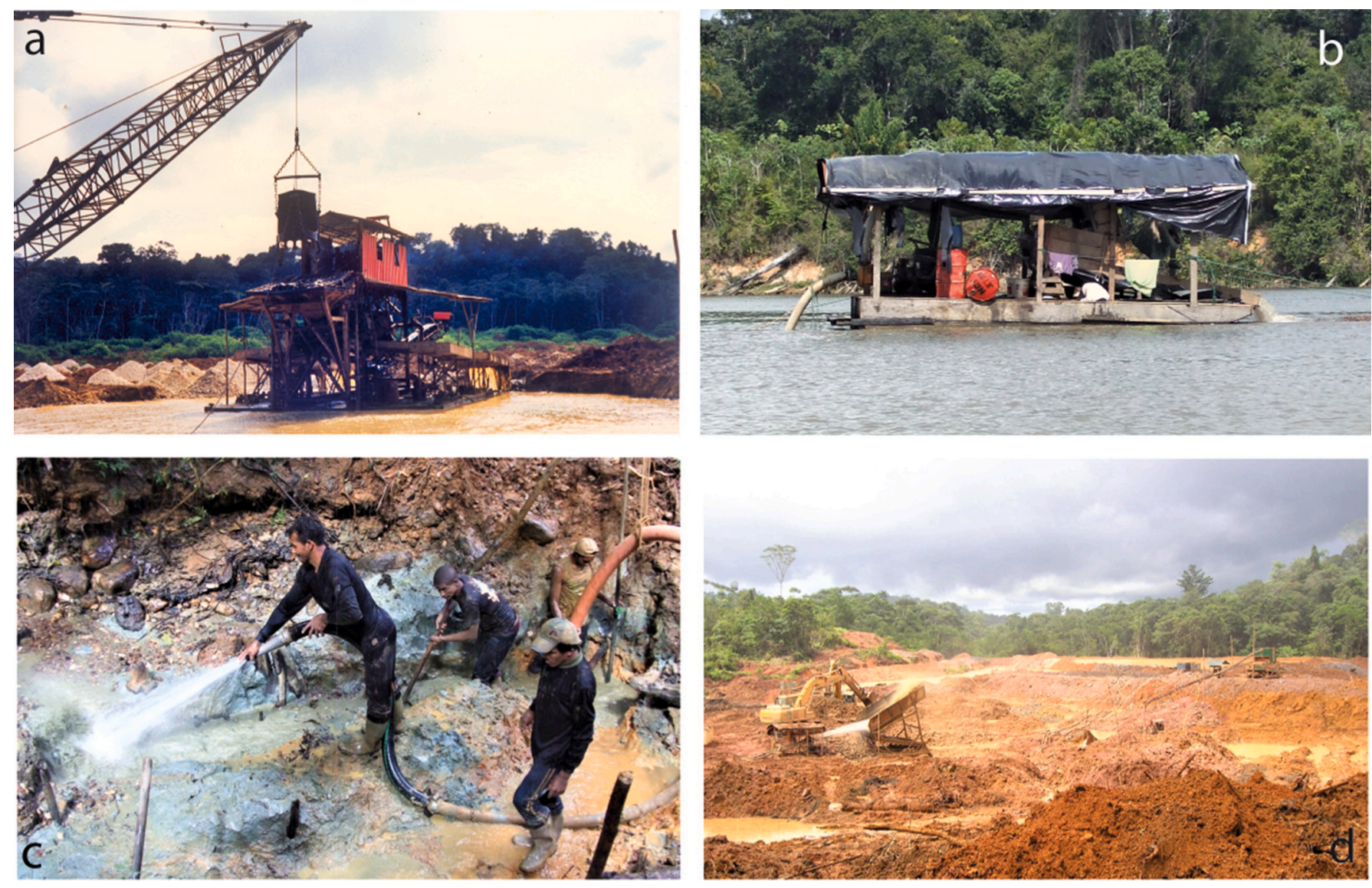

Fig. 6. Gold mining techniques used in French Guiana after WWII. a) Bodinson floating plant and American dragline, Crique Roche, Paul Isnard (Compagnie Minière de Paul Isnard; P. Rostan Collection); b) Suction dredge on the Awa River. This procedure, banned in French Guiana since 1996, is still used in Suriname (2008, Benzdorp; photograph P. Rostan); c) Illegal Brazilian miners monitoring a gravel pump (2008, Crique Roche, Saül, photograph P. Rostan); d) Modern alluvial exploitation showing an excavator, gravel pump, screen with bars ("grizzly") and gold mat (2007, Boulanger Creek; photograph P. Rostan).

Guiana and the neighbouring countries of Venezuela, Guyana and Suriname were affected by the expansion of the gold fronts north of Brazil (Fig. 4). The high ratio of men to women, known to be a good indicator of a pioneering front, identifies lines of penetration along the northern border that cut through pre-existing indigenous reserves (Fig. 4). Starting in 1986, Brazilian miners appeared in French Guiana on the Oyapock River, where suction dredges were still operating. They later reached Suriname along the Maroni River, where they collaborated with the Bushinenge. Several other events amplified the situation, such as the closure of the Serra Pelada gold mine in Pará in 1992, which pushed miners to new ground, with many Brazilians arriving from the state of Maranhão. Their numbers rose in the early 1990s when they fled the Suriname Interior War (1986-1991) and met a laissez-faire policy in French Guiana (Cremers et al., 2013).

At the same time, European countries set up numerous policies and rules framing the extractive industry after the onset of the Chinese resources supercycle and the implementation of ecological reforms (Jébrak, 2015). These rules, widely accepted in Europe, were applied to French Guiana, directly impacting traditional mining practices.

Mining activities split into three different styles in French Guiana: (1) Small and mid-size companies formally recognized by the authorities, exploiting secondary deposits or weathered primary deposits and producing around 1 tonne of gold per year; (2) Major international companies (mainly Canadian), exploiting large but previously unmined deposits (more than one million ounces) using industrial-scale open pit operations, and (3) Illegal mining, mainly carried out by Brazilians, which is responsible for most of the gold production (more than $8 \mathrm{t}$ per year).

Small and mid-size mining operations have continued to work historical placers and weathered primary deposits but with limited production. Up to 30 small companies belonging to local or Metropolitan financial interests specialize in mining secondary gold. They use geologists, innovative tools and a mainly Brazilian workforce. The 1980s saw the introduction of Brazilian gold mining methods, such as high-pressure jets and gravel pumps widely used in the states of Parà and Roraima (Orru, 1999b). Gold is recovered using a carpeted table, and the concentrate amalgamated with mercury. It led to a revival of alluvial activity that reached a production of about 4 tonnes in 2001. The mid-sized companies attempted to follow the strict European rules (Mattheus, 2018), namely the regulation of high-pressure water jets and gravel pumps in 1996 and the ban of mercury in 2013. Techniques switched first to gravimetric methods. Leaching techniques, which use cyanide to recover fine gold from oxidized ore, was applied for the first time to the Changement deposits near Boulanger (1987 to 1997). Auplata installed a cyanidation unit at Dieu-Merci in 2019.

In Suriname, during the Interior War (1986-1991), the Bushinenge became more involved in artisanal mining (De Kom et al. 1998). When they fled the war, they settled along both banks of Maroni, some becoming artisanal gold miners using basic methods. Helped by the Brazilian workforce and know-how, the Bushinenge are now the main players in this economy along the Maroni River, using barges on the Surinamese side to excavate alluvial and eluvial deposits since 2000. Simultaneously, to the south, the Maripasoula region became the primary entry point into the largest European conservation park and the 
core of artisanal mining, both legal and illegal (Luning and de Theije, 2019).

However, the lack of capital and the maladjusted French-European regulations severely hampered the development of local mining industries (Delamarche, 2019). Cumulative production from legal mining decreased to about 1 to 1.5 tonnes of gold per year despite the high price of gold.

Canadian companies increased exploration expenditures in Latin America from US\$150 million to US\$950 million annually between 1990 and 1996 (Heidrich, 2016), reflecting long-term Canadian government policies to promote the internationalization of its mining industry. Following the BRGM's publication of geochemical maps of French Guiana (Magnien et al., 1990), the French Government issued an international tender for prospecting. Several international mining companies, such as Guyanor (Golden Star), Asarco and KWG (Franc-Or Resources Corp. of Canada), answered the call and developed exploration programs. Junior companies sold their most promising projects to a few major companies, in particular Montreal-based Cambior, founded in 1986. The latter turned to the Guiana Shield, where the geology is similar to the Superior Craton of Canada and where they could send French-speaking geologists from Quebec (1995). The company received three licences to explore the Camp Caiman deposit. Around the same time, the French Ministry of Environment recognized the high level of biodiversity in the area and classified it as a natural reserve (1997). The ensuing debate pitted environmentalists against industrialists. The controversy was politically resolved by a decision from the French president to stop Cambior's project in 2008 (Alain et al., 2008), which coincided with a drop in the international price of gold.

Following the Camp Caiman crisis, the French authorities subdivided French Guiana territory into zones: open, open with restrictions, and closed to mining (Fig. 3; SDOM, 2011 in Thomassin et al., 2017). The local authorities strongly contested this plan. The protection policy was strengthened after the Guyana Amazonian Park was established in 2007. This led to a rapid reduction in legal mining activity, as shown by the drop in gold production since 2011 (Fig. 2).

However, the potential for gold demonstrated by BRGM's studies still attracted mining investment from 1996 onwards. The most recent attempts to develop large industrial mines were led by the Columbus Gold-Nordgold Montagne d'Or project. The considerable mining potential of this deposit ignited heated debates about the compatibility between open pit mining and the conservation of biodiversity in the Amazon rainforest. At the Camp Caiman Project, Amerindians, long neglected by the authorities, and environmentalists ('green activists'), often expatriates from Metropolitan France, opposed the proposed mine, whereas most local authorities first supported the project (Tiouka, 2016). Both debates have called into question the likelihood of developing major industrial mining projects in French Guiana.

Fig. 3d illustrates the present-day situation of legal mining in French Guiana. It is notable that most licences, in terms of surface area, are exploration claims. Since exploitation ceased on most of the largest concessions during the last few years, the area covered by active exploitation is currently less than the mapped areas shown in the figure. By June 2020, except for the Dieu-Merci Auplata plant expected to be operational before the end of 2020 , gold exploitation has been limited to alluvial deposits (about 75 licenses of $1-\mathrm{km}^{2}$ each, roughly 30 of which are active). The annual gold production in French Guiana has decreased from about 4 or 5 tonnes in the early $200 \mathrm{~s}$ to about 1.5 tonnes.

Illegal mining increased significantly in the 1990s, a consequence of Brazilian immigration. Artisanal mining has seen a resurgence in the Guianas since 2000 in response to the rising price of gold (Asner et al., 2013). In 2018, between 6000 and 10,000 people were working illegally at approximately 700 gold mining sites in the Amazon rainforest of French Guiana (Melun and Le Bihan, 2020; Fig. 3). These garimpeiros were illegal immigrants from the poorer states of northeastern and southern Brazil, either crossing the border by land or, more recently, taking the plane from Belem to Paramaribo. They do not think of
Suriname, Guyana, and French Guiana as separate nations (De Theije and Heemskerk, 2009; Granger 2017). Sponsors are often traders operating out of Brazilian border towns along the Oyapock River, but some are also Creole or Metropolitan French (Orru, 1999a). Clandestine networks provide the miners with equipment and Brazilian food supplies upstream along the Approuague and Oyapock rivers and their tributaries (Granger, 2017).

Brazilian migrants living in small-scale gold mining areas are often poorly educated and suffer from numerous diseases, including malaria, leishmaniasis, dengue or chikungunya (Douine et al., 2018). However, they bring with them more sophisticated hydraulic equipment such as small portable pumps (Cremers et al., 2013) and experience with excavators, bulldozers, tractors and underground mining. Moreover, Brazilian miners run their small-scale mining operations as professional businesses, working in teams of specialized workers during fixed working hours and with an established hierarchy (De Theije and Bal, 2010).

The French authorities and ONG use remote sensing to map illegal mining activity by tracking evidence of deforestation attributed to illegal mining (Fig. 3d). The affected land appears to cover a larger and more widespread area than the legal licenses. Moreover, illegal mining not only takes place in areas covered by legal licences but also in places where mining is restricted or forbidden.

Since 2008, the French army pursued illegal Brazilian workers as part of Operation HARPIE, forcing them to shift their approach, adopting new miniaturized mining technologies (lighting, ventilation, etc.) and moving underground using shafts and galleries. In $2019,10 \%$ of the gold sites exploited primary deposits using shafts (Melun and Le Bihan, 2020).

\section{Discussion}

Since the Columbus era, South America has been the continent where mining has been the most preeminent, playing a major role in economic development, with extractivist conflicts and commodity wars (Ocampo, 2017). The frontier paradigm has been discussed from Brazil to Bolivia and from Ecuador to Argentina (Schmink and Wood, 1992; Restrepo Botero and Galeano, 2017). Although they share a common Iberian heritage, each country displays specific parameters related to their geography, history and economy. French Guiana is an exception to this landscape because it has been a French territory for 400 years and remains the last ground in the mainland Americas controlled by a non-American power.

Using Moore's (2010) distinction, two aspects of the commodity frontier in French Guiana should be discussed: (1) How did the frontier widen? Is it possible to define a single commodity frontier as is recognized in other gold-rich territories? (Barbier, 2012); (2) Why did the frontier never deepen, i.e. evolve toward industrialization?

\subsection{Geography of the frontiers}

The widening of a frontier corresponds to the geographical expansion into new frontier zones (Moore, 2010). In French Guiana, there have been two phases of expansion measured in terms of mining claims and activities; they are clearly associated with global commodity market variations, i.e. the price of gold (Fig. 2). The first gold rush corresponded to second half of the 19th century during the gold standard period, which coincided with the emergence of colonial capitalism (Hammond et al., 2007), whereas the second reflected the Chinese supercycle that began in 1990 . The retreat of the frontier seems to be causally related to the drop in the price of gold after 1920 and the introduction of the Bretton Woods agreement in 1945. It would seem that below US\$50 per ounce, gold is uneconomical to exploit in French Guiana, even at the artisanal scale.

The two gold rushes in French Guiana followed different distribution patterns (Fig. 3). The first rush moved westward then southward. The 
commodity frontier began on the placer gold deposits in the Northern Greenstone Belt. It expanded toward the hinterland and produced the first 'mining islands' in the rainforest, accessible via large rivers. This period was a pivotal phase characterized by the intermingling of people from diverse ethnic origins who shared the El Dorado dream. Brazilians played a limited role because gold mining in Brazil was mostly concentrated in Minas Gerais, one of the southernmost states, far from French Guiana (Machado et al., 2001). In French Guiana, the gold frontier began to follow the classic evolution from early explorers toward mid-size companies. However, after 1920, the frontier disintegrated, reverting to its initial natural state, and population numbers dwindled (Fig. 3). The Amazon rainforest, the long rainy season, coastal trading challenges, and the difficult access to the hinterland all hindered mining exploration and exploitation. Numerous technologies imported from Western Africa by French engineers failed because they were ill-suited to the harsh environment. Even before the drop of the price of gold, limited extractive activities and isolated mine sites suffered from the lack of physical and economic links to the coastal regions. And although more developed, even the coastal areas did not have the human, technical and financial capacities to support an inland industry. In addition to this, France could not fully control the territory and provide protection from the marauders. Moreover, mainland France was more occupied with European issues starting in 1914.

The second rush generated a much more complex configuration, combining southward and northward movements. In the north, exploration and production involved small and mid-size companies, with local input from international juniors and majors. Substantial North American investments made it possible to develop large gold deposits (Camp Caiman, Montagne d'Or, Espérance). The southern borders of the three Guianas never been fully recognized on the ground, causing several conflicts, often revolving around gold occurrences (Hoefte et al., 2015). The French government thus tried to formalize its presence through institutionalization: between 1930 and 1969, the Territoire de l'Inini (Thabouillot, 2016) was set up to develop the exploitation natural resources and it established Guiana Amazonian Park in 2007 to protect biodiversity. But most artisanal miners were trying to escape poverty, coming from either Suriname or Brazil through semi-permeable borders. This southern frontier was sustained by garimpeiros and local Bushinenge, who were already present in the upper part of the Maroni River. Brazilian migration to French Guiana must be interpreted from a regional perspective, that of northward progression from the Brazilian front (Cleary, 1993; De Theije and Heemskerk, 2009). The infiltration of Brazilian garimpeiros along the Southern Greenstone Belt could be compared to the artisanal frontier in West Africa (Kopytoff, 1987).

The current commodity frontier in French Guiana is a combination of an industrial front in the north and an artisanal front in the south. They contribute relatively little to the territory's economic development as neither the State nor components of the local population fully support the former, and the latter is mostly illegal.

\subsection{Deepening of the frontier}

Deepening corresponds to the intensification of appropriation through increased inputs and various social and technological innovations (Verbrugge and Geenen, 2019). In French Guiana, such deepening never forged sustainable links between the mining sites and the littoral population centres. The first gold rush was not followed by the installation of farmers, as described by Turner (1893) in North America. Without the crucial role they play in territorial re-organization, it was impossible to network the territory and accumulate capital within the national economy (Cleary, 1993). Industrialization remained limited, as in most tropical frontiers (Moore, 2010).

However, the history of gold mining in French Guiana is tied to a series of technological leaps that helped circumvent natural constraints, providing access to new deposits and reviving the economic potential of others. About 30 years after gold was discovered, high-grade alluvial deposits had been depleted. The introduction of dredges allowed previously untouched alluvial deposits to be exploited in the live riverbed or below the water table. When this technique was abandoned 25 years later, it did not stop placer mining. After WWII, motorization helped revive such deposits by increasing the treatment capacity, making lower-grade deposits cost-effective. In the 1950s, the arrival of American draglines and floating plants revitalized placer mining. In the 1980s, suction dredges created new opportunities to exploit live riverbeds, which had been abandoned about 50 years before. The mining of primary gold deposits followed a similar evolution. Underground mining and crushing plants were introduced around 1880 and persisted locally until the 1960s thanks to progressive technical innovations. Finally, modern earthmoving machines and water management techniques became universal tools in exploiting small rivers, alluvial terraces, underwater alluvial sediments, and open-pit primary deposits.

During the second gold rush, land speculation never pushed the conquest movement inward due to the lack of infrastructure and the fact that $90 \%$ of the territory remains the State's private domain. French Guinea never connected to the flow of international investments, as was the case in Suriname and Guyana, where British capital was invested at the beginning of the 20th century (Jong and Boersema, 2005), followed by North American capital in the second half of the century. The industrialization was affected. As a result, the commodity frontier's evolution in French Guiana is indirectly connected to major streams in the capitalist system (Verbrugge and Geenen, 2019). Several factors can explain this outcome, including (1) the local geography and geology, (2) the local population history, knowledge and innovation capacity, and (3) the political specificities of French Guiana in South America.

The natural endowment of French Guiana is similar in many ways to that of its neighbours on the Guiana Shield. The same greenstone belts host the same gold mineralization styles, both primary and secondary. The same Amazon rainforest covers the land. Geology alone cannot explain the specificities of the mining development in French Guiana. Still, the relatively infertile soils and difficult access, like much of the Amazonian basin, must have played a role early on (Le Tourneau, 2009).

The sparse population has been a prominent characteristic in the Guianas. The territory emptied after Amerindian tribes were decimated by European diseases soon after colonization. In contrast to many other Latin American countries, Amerindians were never a workforce and were only recently assimilated (Davy et al., 2016). Demography has therefore been a constant preoccupation for the authorities in French Guiana and was a key element in its immigration policies (slave trade, development of a penal colony, more recent acceptance of Laotian refugees, etc.). The population peaked in 1911 during the first gold rush but declined soon after (Fig. 2). The fact that French Guiana has always been more sparsely populated than other countries appears to be a first-order explanation for the weak commodity frontier south of the coastal plain (Hoefte et al., 2015). Moreover, the education system was undeveloped for a long time; to this day, the educational base of French Guiana is insufficient for training technicians in adequate numbers. Qualified people still need to be outsourced from Metropolitan France.

Until 1946, French Guiana was managed by the French authorities as a colony. At first glance, such management should have been a competitive advantage for the territory, with a quality legal system and easy access to human and financial resources. However, empirical evidence between former French colonies, especially in Africa and East Asia (Assenova and Regele, 2017; Bergh and Fink, 2018), suggests that they commonly suffered from trade protectionism, embedded mercantile and civil law institutions, and a centralization of power in Paris that restricted development (Tadei, 2018). French Guiana was no exception, and its situation did not change with its change in political status.

The last parameter controlling the evolution of the extractive frontier is the uniqueness and isolation of French Guiana. It is by far the most isolated of the Guianese territories, and the economy is more tightly bound to Europe (Hoefte et al., 2015). This high degree of dependence on Paris and Brussels reduces the need for autonomous development in 
French Guiana, and therefore the need for an effective extractive frontier. This makes French Guiana fundamentally different from its neighbours. Despite a resurgence in the price of gold at the end of the Bretton Woods period in 1973, neither international mining companies nor French national mining groups ever invested significantly in French Guiana.

The lack of mining development in French Guiana, or to use Moore's approach (2010), the 'shallowness' of the commodity frontier, resulted from a combination of factors, including unfavourable environmental conditions, the scarcity of people relative to land, the Paris-driven political system, and the territory's isolation from its neighbours. The recent increase in gold mining production, both industrial and artisanal (Verbrugge and Geenen, 2019), reflects the rise in the international price of gold that allows many players to hope for, and sometimes achieve, greater profit margins. But this economic explanation is superimposed on long-term migratory movements, such as the northward migrations of Brazilians (Le Tourneau, 2019) and the long-term migration of overpopulated Caribbean islands into the South American continent (Borda et al., 2008). The economy has been modulating the intensity of people's movements for more than a century.

Moreover, a key specificity of the French Guiana situation is that the political and administrative divisions and hierarchies do not correspond with the situation on the ground. It is not the local socio-political structures and land tenure systems that govern the mining evolution but the different visions that are developed outside the territory for the most part. In northern French Guiana, the mining policy is mainly governed by the Metropolitan authorities in Paris. France's long-term protectionist policy vis-à-vis foreign investments has thus played a major role in limiting the development of industrial mines. In the southern part, the occupation of the territory by illegal miners is related to the Brazilian situation and the conflict between garimpeiros and Brazilian security forces (Cope and Parks, 2016).

Widening and deepening are not independent. Both reflect the territory's long resistance against the expansion of the extractive industry (Cleary, 1993). French Guiana illustrates the viscous character of the commodity frontier in dense rainforests, in contrast to the fluidity of mining development in open deserts. More generally, France's remote management of economic development has hindered infrastructure development, which is essential to both the enlargement and deepening of the border, particularly in a continental territory covered with tropical forests. Extractive frontiers are both economic and political objects.

\section{Conclusion}

The Guianas are at the crossroads of several worlds. They are the link between the Spanish Caribbean, where Christopher Columbus discovered gold, and Lusitanian Brazil, a vast territory with an active northern development frontier. French Guiana adds to this diversity the special status of a French territory in South America. Several key points come to light when the frontier concept is applied to the history of gold mining in French Guiana.

French Guiana experienced two gold rushes influenced primarily by the international price of gold. The first was during the gold standard period, at the end of the 19th century, and the second during the Chinese supercycle at the end of the 20th century. After 1910, the frontier disintegrated due to the remoteness of the mine sites, the limited economic capacities of the coastal regions, and the State's inability to control the territory. The current commodity frontier in French Guiana combines an industrial front in the north and an artisanal illegal front in the south. They contribute relatively little to the territory's economic development as neither the state nor some components of the local population fully support the former, and the latter is mostly illegal.

The mining panorama of French Guiana is that of heterochronous development in which different technologies coexist, reflecting different levels of investment and industrial construction. Despite several attempts, the gold industry has never reached modern standards of production. The lack of mining development in French Guiana, or to use Moore's approach (2010), the shallowness of the commodity frontier, resulted from a combination of factors, including unfavourable environmental conditions, the sparse population relative to land, the Parisdriven political system, and the territory's isolation from its neighbours.

Our study raises numerous questions. Focusing on French Guiana, we did not consider in detail the territory's connections to other countries. Populations, especially the Bushinenge, and technologies, policies, myths, and, more rarely, funding, have been exchanged and shared. Comparative historical studies could lead to a better understanding of long-term inter-Guianese dynamics. Moreover, the frontier concept should be revisited in the tropical context (Geiger, 2009). Subjected to limited technologies and the absence of stable infrastructure, the environment recovers and even erases all traces of the commodity frontier, leaving little material for industrial archaeologists. But even if subjected to more intensive technologies, would a commodity frontier ever be compatible with environmental conservation?

\section{Acknowledgements}

The authors thank the Université du Québec à Montréal and the Université de Guyane for supporting our research. Michel Jébrak thanks the NSERC for funding, and CMO and Columbus Gold for past travel expenses. The authors thank Thibaut Brouard (Pôle Technique Minier de Guyane/Collectivité Territoriale de Guyane) for providing data and expertise regarding current legal mining activities in French Guiana, and Sébastien Linares (EMOPI) for his expertise and advice regarding present-day illegal mining. This paper has been written independently and does not represent the position of any company. Venetia Bodycomb edited a draft of this paper. Two anonymous reviewers and the editor are thanked for their incisive and pertinent comments.

\section{References}

Abonnenc, E., Jolivet, M.J., 1979. Histoire coloniale. In: La Guyane, 4. Atlas des DOM, p. 19. ORSTOM-CEGET, Paris-Talence, planche.

Alain, Y.M., Hirtzman, P., de Chalvron, J.G. (2008) Projet d'exploitation par la société CBJ-Caïman/Iamgold d'une mine d'or à Roura (Guyane) et perspectives d'élaboration d'une politique minière en Guyane. Rapport IGE 07/047, CGM 9/ 2007, IGA 08-003-01, 47 p.

Asner, G.P., Llactayo, W., Tupayachi, R., Luna, E.R., 2013. Elevated rates of gold mining in the Amazon revealed trough high-resolution monitoring. PNAS 110, 18454-18459.

Assenova, V.A., Regele, M., 2017. Revisiting the effect of colonial institutions on comparative economic development. PLoS ONE 12 (5), e0177100.

Barbier, E.B., 2005. Scarcity and Frontiers. How economies Have Developed Through Natural Resource Exploitation. Cambridge Univ. Press, p. 748.

Barbier, E.B., 2012. Scarcity, Frontiers and Development. Geograph. J. 178, 110-122.

Barney, K., 2009. Laos and the making of a 'relational' resource frontier. Geogr J 175 , 146-159. https://doi.org/10.1111/j.1475-4959.2009.00323.x. DOI: i.

Bergh, A., Fink, G. (2018) The French curse? On the puzzling economic consequences of French Colonization. IFN Working paper No 1234, Stockholm, Sweden. 17 p.

Billington, R., 1966. America's Frontier Heritage Holt. Reinhart and Winston, New York, p. 302.

Borda, P., Maurin, A., Manioc, O., 2008. L'immigration intra-caribéenne. In: Des Faits Aux Enjeux Économiques, 1274. Hommes et migrations, pp. 15-20.

Bureau, G., 1935. La Guyane méconnue. Fasquelle Edi., p. 164.

Caviglia-Harris, J.L., Sills, E.O., Mullan, K., 2013. Migration and mobility on the Amazon frontier. Popula. Enviro. 34, 338-369.

Choubert, B., 1952. La mine d'or de Saint-Élie et Adieu-Vat en Guyane Française. Écho des Mines et de la Métallurgie 20 available on Manioc.com.

Cleary, D., 1993. After the frontier: problems with political economy in the modern Brazilian Amazon. J. Lat. Am. Stud. 25, 331-349.

Collomb, G., 2006. Disputing aboriginality: French Amerindians in European Guiana”. In: Maximilian, C. (Ed.), Indigenous Resurgence in the Contemporary Caribbean: Amerindian Survival and Revival. Forte. New York: Peter Lang, p. 298.

Cope, J.A., Parks, A., 2016. Frontier Security: the Case of Brazil. Institute for National Strategic Studies, Strategic Perspectives. Mo20. NDU Press, Washington, DC, p. 56.

Coudreau, H.A. (1887), La France equinoxiale, t. II - Voyage à travers les Guyanes et l'Amazonie, Challamel Ed., Paris.

Cremers, L., Kolen, J., de Theije, M., 2013. Small-scale gold mining in the Amazon. The Cases of Bolivia, Brazil, Colombia, Peru and Suriname. Cuadernos del CEDLA 26. CEDLA, Amsterdam available on GOMIAM website.

Daget, S., 1992. Main D'œuvre Et Avatars Du Peuplement En Guyane française, 18171863, 297. Revue française d'histoire d'outremer, pp. 449-474. https://doi.org/ 10.3406/outre.1992.3049, 79. 
Daly, S., 2018. From the Erzgebirge to Potosi. A History of Geology and Mining Since the 1500's. Friesen Press, Victoria, Canada, p. 138.

Dangloise, A., Pottereau, L., 1905. Notes, essais et études sur la Guyane Française et le développement de ses ressources variées et spécialement de ses richesses aurifères filoniennes et alluvionnaires. Ficker, 2nd Ed., p. 28 Parisavailable on Manio.Org.

Chapt. 16, in Da Silva Enriquez, M.A, Drummond, J.A, Sayago, D, Tourrand, J.F, Bursztyn, M, Drummond, J.A., 2010. Construction de la frontière minière en Amazonie dans la seconde moitié du XXe siècle (coord.). L'Amazonie, un Demi-siècle Après la Colonisation 299. Ed. Quae-INRAISBN 978-2-7592-0327-7.

Davy, D., Filoche, G., Guignier, A., Armanville, F., 2016. Le droit foncier chez les populations amérindiennes de Guyane française: entre acceptation et conflits. In: justices en guyane: à l'ombre du droit. Revue d'Histoire de la Justice 26, 223-236. ISSN 1639-4399.

De Jong, E.B.P., Knippenberg, L., Bakker, L., 2017. New frontiers: an enriched perspective on extraction frontiers in Indonesia. Crit. Asian Stud. 39 (3), 330-348. https://doi.org/10.1080/14672715.2017.1333267.

De Kom, J.F.M., Van der Voet, G.B., de Wolff, F.A., 1998. Mercury exposure of Maroon workers in the small-scale gold mining in Surinam. Environ. Res. 77, 91-97.

Delamarche, M. (2019) La Guyane fait grise mine. Usine Nouvelle, 12/07/19, available on Usinenouvelle.com.

De Theije, M., Heemskerk, M., 2009. Moving Frontiers in the Amazon: brazilian smallscale gold miners in Suriname. Eur. Rev. Latin Am. Caribbean Stud. 87, 8-25.

De Theije, M., Bal, E.W., 2010. Flexible migrants: brazilian gold miners and their quest for human security in Surinam. In: Eriksen, T.H., Bal, E.W., Salemink, O. (Eds.), A World of Insecurity: Anthropological Perspectives On Human Security (Anthropology, Culture and Society). Pluto Press, London/New York, pp. 66-85.

Domenach, H., Picouet, M., 1992. La Dimension migratoire des Antilles, coll. "CaraïbeAmérique latine. Economica 254. Paris.

Douine, M., Mosnier, E., Le Hingrat, Q., Charpentier, C., Corlin, L., Adenis, A., Lazrek, Y., Niemetsky, F., Aucouturier, A.L., Demar, M., Musset, L., Nacher, M., 2018. Illegal gold miners in French Guiana : a neglected population with poor health. BMC Public Health 18, 23.

Fleury, M., 2018. Gaan Mawina, le Marouini (haut Maroni) au cœur de l'histoire des Noirs marron Boni/Aluku et des Amérindiens Wayana. Ethnoécologie 3. https://doi. org/10.4000/ethnoecologie.3534.

Fortes-Lima, C., Gessain, A., Ruiz-Linares, A., Bortolini, M.-.C., Migot-Nabias, F., Bellis, G., Moreno-Mayar, J.V., Restrepo, B.N., Rojas, W., Avendano-Tamayo, E., Bedoya, G., Orlando, L., Salas, A., Helgason, A., Gilbert, M.T.P., Sikora, M., Schroeder, H., Dugoujon, J.M., 2017. Genome-wide ancestry and demographic history of African-descendant Maroon communities from French Guiana and Suriname. Am. J. Human Genetic 101, 725-736.

Galmot, J. (1907) L'illustration, 3358, july 6.

Geiger, D., 2009. Turner in the Tropics: The Frontier Concept Revisited. PhD Thesis. University of Luzern.

Godfrey, B.J., 1992. Migration to the gold-mining frontier in Brazilian Amazonia. Geogr Rev 82 (4), 458-469.

Granger, S., 2017. Migrations et continentalisation en Guyane. Territoire en mouvement Revue de Géographie et D'aménagement 36. https://doi.org/10.4000/tem.428. URL. http://journals.openedition.org/tem/4281.

Grätz, T., 2004. Les frontières de l'orpaillage en Afrique occidentale. Autrepart 30 (2), 135-150.

Guiraud, J., Tremblay, A., Jébrak, M., Ross, P.S., Lefrançois, R., 2020. Stratigraphic setting and timing of the Montagne d'Or deposit, a unique Rhyacian Au-rich VMS deposit of the Guiana Shield. Precambrian. Res. 337, 105551.

Hammond, D.S., Gond, V., de Thoisy, B., Forget, P.-.M., DeDijn, B.P.E, 2007. Causes and consequences of a tropical forest gold rush in the Guiana shield, South America. Ambio 6 (8), 661-670. Dec;3.

Heidrich, P., 2016. Determinants, boundaries, and patterns of Canadian mining investments in Latin America (1995-2015). Lat. Am. Policy 7, 195-214.

Heemskerk, M., 2000. Driving Forces of Small-Scale Gold Mining Among the Ndjuka Maroons: a Cross Scale Socioeconomic Analysis of Participation in Gold Mining in Suriname. PhD Dissertation. University of Florida, USA.

Hoefte, R., Bishop, M.L., Clegg, P., 2015. Still lonely after all these years? Contemporary development in the 'Three Guianas'. Caribbean Stud. 43, 83-113.

Hoogbergen, W., Kruijt, D., 2004. Gold, garimpeiros and maroons: brazilian migrants and ethnic relationships in post-war Suriname. Caribbean Stud. 32, 3-44.

Hyles, J.R. (2014) Guiana and the shadows of Empire: colonial and cultural negociations at the edge of the world. Lanham, MD, Lexington, $202 \mathrm{p}$.

Jébrak, M., 2015. Quels Métaux Pour Demain ? Les Enjeux Des Ressources Minérales. Dunod, Paris.

Jolivet, M.J., 1982. La Question créole, Essai De Sociologie Sur La Guyane Française. Orstom éditions, Paris, p. 503, 1982.

Jolivet, M.J. (2019) Territorialisation et historicité en Guyane. Cahiers de l'Urmis. Aux frontières de l'Autre : territoire et appartenance en question, 18, $22 \mathrm{p}$.

Jong, L.de, Boersema, D.A.A., 2005. The Kingdom of the Netherlands in the Caribbean. Purdue University Press, West Lafayette, IN, pp. 1954-2004.

Josiah, B.P., 2011. Migration, mining and the African diaspora. Guyana in the Nineteenth and Twentieth Centuries. Palgrave Mac.

50 Kopytoff, I. (Ed.), 1987. THE African Frontier: The Reproduction of Traditional African Societies. Indiana University Press, Bloomington, p. 296.

Kröger, M., 2017. The changing modalities of 'Frontiers of Existence' and 'commodity/ resources frontiers': preliminary notes based on deforestation in Brazil. In: The 5th Conference of the BRICS Initiative for Critical Agrarian Studies. Moscow, Russia, p. 25. RANEPA. Conference paper 1; 13-16/10/17.
Kroonenberg, S., Masson, P.R.D., Kriegman, L., de Roever, E.W.F., Wong, T.E., 2019. Geology and mineral deposits of the Guiana Shield. Mededeling Geologisch Minbouwkundge Dienst Suriname 29, 111-115.

Lenormand, J., Lenormand, J.-P., 1952. In: L'or et le diamant en France métropolitaine et dans l'Union française, p. 606. Éd. SEF.

Le Tourneau, F.M., 2009. La distribution du peuplement en Amazonie brésilienne: l'apport des données par secteur de recensement. L'espace Géographique 38, 359-375. https://www.cairn.info/revue-espace-geographique-2009-4-page-359. htm.

Le Tourneau, F.M., 2019. L'Amazonie. Histoire, Géographie, Environnement. CNRS Éditions, Paris

Levat, D., 1902. La Guyane Française En 1902. Dunod Editeur, p. 114p.

Luning, S., de Theije, M., 2019. Rubbish at the border: a minefield of conservationist politics at the Lawa River, Suriname/French Guiana. In: Pijpers, R.J., Eriksen, T.H. (Eds.), Mining Encounters: Extractive Industries in an Overheated World. Pluto Press, London, pp. 59-77.

Machado, I.F., de, M., Figueirôa, S.F., 2001. 500 years of mining in Brazil: a brief review. Res. Policy 27, 9-24.

Magnien, A.P., Plat, R., Coste, B., Le Chapelain, J.R. (1990) Inventaire minier du département de la Guyane. Avancement des travaux au 3 août 1990. Rap. BRGM R 31286, 34 p. Avalaible on http://infoterre.brgm.fr/rapports/RR-31286-FR.pdf.

Mam Lam Fouck, S. (1999) La Guyane française au temps de l'esclavage, de l'or et de la francisation (1802-1946), Ibis Rouge Éditions, Petit-Bourg, Guadeloupe, 388 p.

Mam Lam Fouck, S, 2002. Histoire Générale de la Guyane Française., 2nd Ed. Ibis Rouge Ed, Cayenne, French Guiana, p. 264.

Mattheus, P., 2018. Les techniques et conditions des mines aurifères. Annales des Mines Réalités Industrielles 2018 (4), 10-19.

Melun, G.Le Bihan, 2020. Histoire et impacts environnementaux de l'orpaillage en Guyane. Clefs de compréhension des tensions actuelles. Office Français de la Biodiverssité, coll. Comprendre pour agir, p. 104.

Milési, J., Egal, E., Ledru, P., Vernhet, Y., Thiéblemont, D., Cocherie, A., Tegyey, M., Martel-Jantin, B., Lagny, P., 1995. Les minéralisations du Nord de la Guyane française dans leur cadre géologique. Chronique de la Recherche Minière 518, 5-59.

Moore, J.W., 2000. Sugar and the expansion of the early modern world-economy: commodity frontiers, ecological transformation, and industrialization. Review: Fernand Braudel Center 23, 409-433.

Moore, J.W., 2010. The end of the Road? Agricultural revolutions in the capitalist worldecology, 1450-2010. J. Agrarian Change 10, 389-413.

Moore, J.W. (2014) The Capitalocene, Part II: abstract social nature and the limits to capital, 52 p. avalaible on https://www.researchgate.net/publication/264457281al.

Ocampo, J.A., 2017. Commodity-led development in Latin America. Int. Devel. Policy 9, $51-76$.

Orru, J.F., 1999a. Inventaire historique de l'activité d'orpaillage en Guyane française. Le mercure en Amazonie, Annexe 12, 409-424.

Orru, J.F., 1999b. Typologie des exploitations aurifères de Guyane et spécificités du contexte socio-économique local. Le mercure en Amazonie, Annexe 13, 425-446.

Perez, D.R., 1973. El mito del Dorado: su génesis y proceso. Academia National de la Historia 116, 718.

Petot, J., 1986. L'Or de Guyane. Éditions Caribéennes, p. 248.

Petot, J., 1993. Histoire contemporaine de l'or de Guyane (de 1947 à nos jours). L'Harmattan 255.

Piantoni, F., 2006. Les recompositions territoriales dans le Maroni : relation mobilitéenvironnement. Revue Européenne des Migrations Internationales 18 (2), 37.

Piantoni, F., 2009. L'enjeu Migratoire En Guyane Française. Ibis Rouge Matouri, p. 439.

Restrepo Botero, D.I, Galeano, C.A.P, 2017. Territories in dispute: tensions between 'Extractivism', ethic rights, local governments and the environment in Bolivia, Colombia, Ecuador and Peru. Alternative Pathways to Sustainable Development: Lessons from Latin America, International Development Policy series No.9 (Geneva, Boston. Graduate Institute Publications, Brill-Nijhoff, pp. 269-290.

Richardson, T., Weszkalnys, G., 2014. Ressources Materialities. Anthropol. Quaterly 87, $5-30$.

Rodney, W., 1981. A. History of the Guyanese Working People 1881-1905. Heinemann Educational Book Ltd, London. Kingston, Trinidad. Available on Archive.Org.

Rostan, P., 2007. Exploitation contemporaine de l'or par la technique du creusement au feu à Saül (Guyane Française). Projet Européen Agricola oct 2006-oct 2007, pp. 311-325.

Rostan, P., 2010. Dragosaures. L'aventure des dragues aurifères, les géantes oubliées de l'histoire de l'or guyanais. Une Saison en Guyane 5, 61-67.

Rostan, P., 2013. Une Guyane industrielle ? Entre déshérence et valorisation, état du patrimoine minier de la Guyane française. Karapa 2, 44-56.

Rostan, P., 2014. Les techniques de l'orpaillage artisanal à Saül (Guyane Française), vestiges et impacts sur le paysage. Karapa 3, 73-88.

Saussus, P., Mandrick, P. (2004) De l'or et des mines d'or en France et en Guyane française. Mémoire en images, Alan Sutton ed., St Cyr sur Loire. 128 p.

Scammacca, O., Gunzburger, Y., Medhizadeh, R., 2020. Gold mining in French Guiana: a multi-criteria classification of mining projects for risk assessment at the territorial scale. Extract. Ind. Soc. https://doi.org/10.1016/j.exis.2020.06.020 press.

Schmink, M., Wood, C, 1992. Contested Frontiers in Amazonia. Columbia University Press, New York.

Seyer, P., 1961. L'exploitation mécanisée du placer aurifère de Boulanger en Guyane Française. Mine et Métallurgie 145-150, 3548-3549-3550 Feb pp 83-7, MarApr p $221-4$.

Sponsel, L.E., 1995. Relationships among the world system, indigenous peoples, and ecological anthropology in the endangered Amazon. In: Sponsel, Leslie E. (Ed.), Indigenous Peoples and the Futures of Amazonia: An Ecological Anthropology of an Endangered World. University of Arizona Press, Tucson and London, pp. 263-293. 
Sprague, J., 2015. From international to transnational mining: the industry's shifting political economy and the Caribbean. Caribbean Studies 43, 75-112.

Strobel, M.B., 1998. Les Gens De l’Or. Mémoire des Orpailleurs Créoles Du Maroni. Ibis rouge éditions, p. 400.

Tadei, F., 2018. The log-term effects of extractive institutions: evidence from trade policies in Colonial French Africa. Economic History od developing region 33, 163-208.

Taubira-Delannon, C. (2000) L'Or en Guyane: éclats et artifices: rapport remis au Premier Ministre. La documentation Française, 154 p.

Thabouillot, G., 2016. Le Territoire De L'inini 1930-1969. Ibis rouge éditions, p. 904. Théry, H., 2003. Une guyane brésilienne. Cahiers des Amériques latine 43, 17.

Thomassin J.-.F., Urien, P., Verneyre, L., Charles, N., Gain, R., Guillon, D., Boudrie, M., Cailleau, A., Matheus, Ph., Ostorero, C., Tamagno, D. (2017) Exploration et exploitation minière en Guyane, Collection « La Mine en France », t. 8, février. 141 p. 41 fig., 2 tabl., 7 ann.

Tiouka, A., 2016. Stratégies amérindiennes en Guyane Française. Multitudes 64 , 199-201.

Tsing, A., 2003. Natural resources and capitalist frontiers. Econom. Pol. Weekly 38, 5100-5106 n. 48 (Nov. 29 - Dec. 5, 2003).
Tsing, A., 2005. Friction: A Global Ethnography of Global Connection. Princeton Univ. Press, pp. 1-18.

Turner, F.J. (1893) The Significance of the Frontier in American History. Available on https://s3-eu-west-1.amazonaws.com/s3-euw1-ap-pe-ws4-cws-documents.

ri-prod/9781138824287/ch2/2. Frederick J. Turner, Th

e_Frontier_in_American_History,_1893.pdf.

Urban, Y., 2016. Les conventions entre la France et les peuples marrons du Surinam. Contribution à l'étude des middle-grounds post-esclavagistes. Histoire de la Justice 26, 201-221.

Vanderhaeghe, O., Ledru, P., Thiéblemont, D., Egal, E., Cocherie, A., Tegyey, M., Milési, J.-.P., 1998. Contrasting mechanism of crustal growth: geodynamic evolution of the Paleoproterozoic granite-greenstone belts of French Guiana. Precambrian. Res. 92 (2), 165-193.

Verbrugge, B., Geenen, S., 2019. The gold commodity frontier: a fresh perspective on change and diversity in the global gold mining economy. Extract. Ind. Soc. 6 , 413-423.

Waszkis, H., 1993. Mining in the America. Woohead Pub. Ltd, Cambridge, UK, p. 280. Webb, W.P., 1952. The Great Frontier. Boston. Houghton Mifflin Co, p. 434. 